\title{
PROFESSIONAL EDUCATION AS A VALUE
}

\section{Pahuta M. V.}

\section{INTRODUCTION}

The development of human society is impossible without the transfer of cultural and historical experience from the older generations to the younger. And education has always been and is the way of entry into the world of science and culture. Therefore, in the current conditions of reforming the national education system, it is important to develop the axiological principles, values and ideals of the national education system. After all, it is the value (axiological) foundations of education that form the educational paradigm, which defines the direction, goals and methods of educational activity, ensuring the realization and development of educational inquiries of a society at a particular specific historical stage of its development.

Valuable issues interested people for a long time and today their development remains extremely relevant. The representatives of different sciences (philosophy, sociology, psychology, pedagogy, etc.) who consider values from different points of view were involved in solving this problem. Multidisciplinary approach provides better understanding of the nature of values to justify their classification hierarchy of values and the like. Significant interest in value issues is justified, because values are not only guidelines for the activities of subjects, means of meeting their needs, but also the vectors of the development of a society, the focus of spiritual life ${ }^{1}$.

A person's life success is closely linked to the activity in which he or she self-realizes. At the same time, the acceleration of economic, social

\footnotetext{
1 Невмержицька О.В. Визначення категорії - цінність - : до історіографії проблеми. // Східноєвропейський історичний вісник / [головний редактор В. Ільницький]. Дрогобич: Посвіт, 2017. Вип. 4. 172 с. Ст. 15-23.
} 
and technological development rates lead to a person's need to improve his professional knowledge and skills ${ }^{2}$. Thus, increasing the public's attention to the development of the education system, including the professional one.

Effective professional education contributes to the development of a person not only as a professional with developed professional competence, but also as a person of high culture, nationally conscious, with developed moral, ecological and economic consciousness, a good citizen of his country and representative of humanity.

At present, a solid, thorough mastery of complex and extensive knowledge that is necessary for successful self-realization of a person in public life is possible only via the educational process. Accordingly, education is regarded by most people as one of the key values of public life. Thus, education is not only a means of transmitting and multiplying socially important values, but also of personal and socially important values.

\section{Value aspects of education}

Education - is the process and result of assimilation by a person of a certain system of scientific knowledge, practical skills and related level of development of his mental-cognitive and creative activity, as well as moral and aesthetic culture, which in its totality determine a social personality and individual identity of that person ${ }^{3}$.

Yes, G. Hegel also noted that it is through education that people learn socially important concepts, principles and norms of behavior. That is why education is the process of human growth over its natural essence through the development of all what is created by mankind throughout its existence ${ }^{4}$. General education is a set of knowledge of basics sciences of nature, society, thinking, art, as well as the relevant abilities and skills

\footnotetext{
2 Ломакина Т. Ю. Современный принцип развития непрерывного образования: монография. М.: Наука, 2006. 221 с.

${ }^{3}$ Енциклопедія освіти / гол. ред. В. Г. Кремень. К. : Юрінком Інтер, 2008. 1040 с. Ст. 614.

4 Гегель Г. В. Ф. Работы разных лет / ред. А. В. Гулыга ; пер. Ц. Г. Арзаканьян, В. А. Рубин, Б. А. Драгун и др. М. : Мысль, 1971. Т. 2. 627 с.
} 
required of every person, regardless of his profession. Mastering general education knowledge is the basis of scientific outlook, contributes to the development of cognitive strengths and abilities. General education is the basis of polytechnic and vocational education ${ }^{5}$.

At the same time, education is not only a process of transferring the experience and knowledge accumulated by a society to a person, but also the development of the individual's personality, his / her consciousness ${ }^{6}$. This makes education one of the key values of the modern world.

In teaching there is no single interpretation of the notions "education" and "vocational education". In particular, A. Khutorskyi ${ }^{7}$ believes that different definitions of "education" reflects some of its facets:

1)education in relation to different subjects: individual, group of students, society, state, humanity, etc .;

2) education as influence on personality and as development of personality;

3) education as a process and result of self-education of an individual;

4) education in relation to education, development or training;

5) education as a process characterized by personality changes over a period of time, and also involves the availability of pedagogical tools;

6) education as a result, which can be formally expressed in the form of a certificate or diploma, or substantively (mathematical or liberal arts education, etc.);

7) education as a system of educational structures ${ }^{8}$.

According to "The Encyclopedia of Education" the notion "education" is considered from several points:

- as a process, that is, a coherent unity of learning, education, development, self-development of an individual, preservation of cultural

\footnotetext{
5 Педагогика: Большая современная энциклопедия / сост. Е. С. Рапацевич. Минск : Современное слово, 2005. 720 с. Ст. 391.

6 Грехнев В.С. Ценностные основания процессов образования и образованности людей в современном обществе // Философия и общество. 2010. № 3. С. 40-55.

${ }^{7}$ Хуторской А. В. Современная дидактика. СПб. : Питер, 2001. 544 с.

${ }^{8}$ Хуторской А. В. Современная дидактика. СПб. : Питер, 2001. 544 с. Ст. 12

${ }^{9}$ Енциклопедія освіти / гол. ред. В.Г. Кремень. К. : Юрінком Інтер, 2008. 1040 с.
} 
norms with orientation to the future state of culture, creation of conditions for full realization of the internal potential of an individual and his becoming as an integrated member of society, fulfilling the function of succession of generations;

- as a socio-cultural component that promotes the economic, social, cultural functioning and improvement of a society through specially organized purposeful socialization and inculturation of individuals, expressed in a system that includes educational institutions, governing bodies, educational standards that ensure their functioning;

- as a result, that is, the level of general culture and education of younger generation, the assimilation of the spiritual and material potential that was accumulated by human civilization in the process of evolutionary development and which aims at further social progress;

- as the most general pedagogical concept, which means both social phenomenon and pedagogical process ${ }^{10}$.

Equally diverse are the approaches to define the notion of "professional education". Thus, in "Sociological and pedagogical dictionary" edited by V. Radul the definition is based on the understanding of education as a system of educational structures: professional education training in educational institutions of specialists of different levels of qualification for work in one of the branches of national economy, science, culture; an integral part of an unified system of public education, the content of which is an in-depth acquaintance with the scientific bases and technology of the chosen type of works; gaining of special practical skills and competences; the formation of psychological and moral qualities of a person, important for work in a certain sphere of human activity ${ }^{11}$.

This approach underlines S. Goncharenko's definition of this notion. The author is convinced that "professional education is the training of specialists at different levels of qualification for employment in one of the

\footnotetext{
${ }^{10}$ Енциклопедія освіти / гол. ред. В. Г. Кремень. К. : Юрінком Інтер, 2008. 1040 с. Ст. 615.

${ }^{11}$ Соціолого-педагогічний словник / за ред. В. В. Радула. Київ : ЕкОб, 2004. 304 с.
} 
branches of national economy, science, culture; an integral component of the time of the unified system of public education"12.

S. Goncharenko also provides a definition based on understanding of education as a sphere of transfer and assimilation of knowledge: "The term "professional education is also understood as a set of knowledge, skills and abilities, mastering which is able to work as a specialist of higher, secondary qualification or skilled worker" ${ }^{\prime 13}$. A similar definition is also formulated by M. Fitsula: it is a set of knowledge, practical skills needed to perform work in a particular field of work ${ }^{14}$.

$\mathrm{N}$. Batechko views professional education as a continuous process, which is conditioned by the needs of an individual, a society and an economic state, and aims at continuous professional and personal development and self-improvement of specialists, expanding their opportunities both within the one chosen profession and in the conditions of changing sphere of professional activity ${ }^{15}$.

In "Pedagogical Encyclopedic Dictionary", edited by B. Bim-Bad, we find definitions that interpret education as a process and a result: it is a socially and pedagogically organized process of labor socialization of an individual, providing orientation and adaptation in the world of professions, mastery of a specific profession and a skill level, continuous growth of competence and skill development in various spheres of human activity that creates conditions for professional formation, development and personal fulfillment and encourage achievement of humanistic and democratic goals of a society ${ }^{16}$.

At the same time, B. Gershunskyi views education as a system, a process, a result and a value. The scientist is convinced that the value

\footnotetext{
${ }^{12}$ Гончаренко С. У. Український педагогічний словник. Київ : Либідь, 1997. 376 с. Ст. 274-275.

${ }^{13}$ Гончаренко С. У. Український педагогічний словник. Київ : Либідь, 1997. 376 с. Ст. 275.

${ }^{14}$ Фіцула М. М. Педагогіка. Київ : - Академвидав, 2005. 560 с.

${ }^{15}$ Батечко Н. Г. Підготовка викладачів вищої школи в умовах магістратури: теоретико-методологічні засади: Монографія / За ред. Я. В. Цехмістера К.: ТОВ - Видавниче підприємство - ЕДЕЛЬВЕЙС, 2014. 708 с. Ст. 138.

${ }^{16}$ Педагогический энциклопедический словарь / гл. ред. Б. М. Бим-Бад. М.: Большая Российская Энциклопедия, 2003. 527 с.
} 
characteristic of education touches education as a state, social and personal value $^{17}$.

Accordingly, we believe that the definition of "professional education" can be given in a somewhat different interpretation: professional education is a process on the basis of which values and norms are transferred in the system of professional development, because knowledge embodies a certain value content.

The value of the term is very complex, it reflects the degree of importance of the object being evaluated, or of an individual, or a society as a whole. The human world is a world of values, which it assimilates, appropriates, transmits and guides in every life situation. It is also the world of values created by a man. Material values satisfy the immediate needs of a man and provide conditions for his survival; social - are the basis of society, and spiritual - contribute to the comprehensive mastery of the world. They determine the outlook of an individual, his attitude to himself and the world.

Cognition of values takes place in an activity that corresponds to the level of the development of each person, his or her life experience, the acquired system of knowledge, etc., and therefore is an extremely individualized process. Each person's world of values develops with him throughout his life in the process of socialization, through the activity he is involved, in which he creates material wealth and at the same time develops his own axiological consciousness. Values structure a person's motivation, determine the hierarchy of his needs. Values are at the heart of human activity, regulating and directing it.

Considering education as a kind of mediator between an individual and a socio-cultural sphere in which this person lives and develops, questions the person's value orientations, peculiarities of their formation and transformation in the process of vocational training come first. Value orientation of a person is formed on the basis of values and a special social

\footnotetext{
${ }^{17}$ Гершунский Б. С. Философия образования. М. : Московский психолого-социальный институт, 1998. 432 c. Ст. 30.
} 
attitude of a person to certain values, which are reflected in the mind of a person in the form of an object, which is necessary for that person to meet his needs. Valuable orientation always arises only in the connection with the actualization of the importance of a certain object in the consciousness of an individual, inclusion in human activity ${ }^{18}$. These value orientations in education in general and vocational education in particular, ensure the formation and development of a personality and professionally consciousness ${ }^{19}$.

One of the most important types of human activity is professional. It provides the opportunity for development, self-improvement, self-realization, provides material and spiritual well-being of an individual and at the same time is an important foundation for economic development, and therefore - social progress.

Subjective factors of successful professional activity are consciousness, spiritual world of a man, his professional training, knowledge, abilities and skills of production activity; social experience, the level of labor culture and ideological orientation and will qualities, creative thinking, talent and abilities, level of education and education rights; the capacity for long-term spiritual, moral and physical stress in the process of work; the degree of realization of freedom and creative potential; value orientations of labor activity ${ }^{20}$.

Accordingly, for both the education system as a whole and professional in particular, it is important to assimilate the personality a set of humanistic and professional values. Professional values, which underlie the axiological approach to professional training of a specialist, are characterized by a measure of dominance, awareness and variability, and represent a set of personal orientations and attitudes, properties and

\footnotetext{
18 Грехнев В.С. Ценностные основания процессов образования и образованности людей в современном обществе // Философия и общество. 2010. № 3. С. 40-55.

19 Алиева Б. Ш. Ценностные ориентации личности в современной парадигме развития профессионального образования // Вестник бурятского государственного университета. Образование. Личность. Общество. 2017. Вып. 3. С. 15-21. Ст. 15-16.

20 Зубов В. А. Труд в ХХІ столетии: особенности развития // Молодой ученый. 2016. № 6. С. 957-961. Ст. 957-958.
} 
qualities on the basis of which a future specialist selects, develops and carries out professional activity.

The essence and content of values of professional education depends considerably on the dynamics of the development of a society, its priorities and dominants. Harmonization of the modern industrial development of a society is possible on the condition of the involvement of an individual in social orientations through their socio-cultural awareness. Especially important it is for the formation of professional and personal values in the systems of professional training. The values of education, as noted by B. Aliyeva with the reference to A. Leontiev, should be approved by a society preserved and passed down from generation to generation in the form of samples of culture reflected in the inner spiritual state of an individual ${ }^{21}$.

Comparing the content of concepts of value orientations, you can distinguish their common and distinctive features. Values are the result of social development, a product of socio-cultural sphere, they are not passed to an individual as a finished product, but people gradually assimilated them and in the structure of human personality are transformed into value orientations, which, in its turn, determine the features of its life.

Values are important elements of the internal structure of personality formed and secured by life experience of an individual, namely they determine the degree of personal importance to humans of certain aspects of his life activity, identify and highlight important aspects out of unimportant, minor for a human ${ }^{22}$.

The combination of the formed value orientations is a kind of skeleton of consciousness of a man, providing the formation of one's own life principles, their stability ${ }^{23}$.

\footnotetext{
21 Алиева Б. Ш. Ценностные ориентации личности в современной парадигме развития профессионального образования // Вестник Бурятского государственного университета. Образование. Личность. Общество. 2017. Вып. 3. С. 15-21. Ст. 16.

22 Алиева Б. Ш. Ценностные ориентации личности в современной парадигме развития профессионального образования // Вестник бурятского государственного университета. Образование. Личность. Общество. 2017. Вып. 3. С. 15-21. Ст. 16.

23 Философский энциклопедический словарь / гл. ред. Л. Ф. Ильичев и др. М.: Сов. энциклопедия, 1983. 839 с. Ст. 764.
} 
Values act as socially constructed individual substructures related to the progressive development of a human as a subject of professional activity and is specific result of internalization by an individual of sociocultural and professional values and forming on their basis of one's own system of personality-significant values. Thus, in the process of development, an individual not only gradually assimilates socio-cultural and professional values, but also transforms them in the creative process of value self-determination ${ }^{24}$.

The formation and development of a person's professional values begins with the process of selection and mastery of the chosen profession and continues throughout the labour activity and provides:

- awareness of one's belonging to a particular professional community;

- change of attitude towards oneself as a professional;

- change of intra-subjective professional ideals;

- changing the criteria for choosing a profession;

- introspection of oneself as a specialist, identification, professionally important strengths and weaknesses, etc. ${ }^{25}$

Professional value orientations play a decisive influence both on the professional, and the personal self-identity. Professional value orientation is dialectical unity of spiritual, rational (real), generally social and individual in a personality. Due to this, professional value orientations are one of the main in the global structure of personality characteristics and an integral structural component of vital self-determination of a personality. It is because of inherent individual professional important value orientations that provide a responsible attitude of people to their activity, stimulates one's creativity and learning.

The modern structure of personality value orientations should include: self-improvement, professional self-determination of a person,

\footnotetext{
${ }^{24}$ Алиева Б. Ш. Ценностные ориентации личности в современной парадигме развития профессионального образования // Вестник бурятского государственного университета. Образование. Личность. Общество. 2017. Вып. 3. С. 15-21. Ст. 16.

${ }^{25}$ Ціннісні парадигми освіти / укл. Н. О. Ткачова. Харків : Основа, 2004. 128 с. Ст. 34.
} 
competitiveness of a person in the conditions of social and crisis phenomena. For example, the loss of a work a man is found in a situation, in which the orientations of rational knowledge do not help to overcome the current difficulties. In such conditions, a person comes to the aid of cultural and moral guidelines that allow him to adapt to the new conditions of society, make the right choice ${ }^{26}$. And thanks to the education industry the internalization of general important (social and professional) values in conscious of a man is provided. However, this internalization of values and priority values occur throughout the life, it determines the success of the socialization of an individual.

Thus, narrowly focused specialization, utilitarianism in the system of organization and functioning of the modern educational industry lead to the fact that the ignorance of certain groups of people of some, necessary for all circles of knowledge, not only complicates and constrains their communication, but also creates certain threats to the civilizational development of a society. After all, people can communicate and understand each other, if they do not have mutual understandin, they are scattered and do not form a single monolithic nation (in the psychological and spiritual aspects), said V. Hrehnev ${ }^{27}$.

That is why education is determined to perform the number of specific functions, which include:

- axiological, which encompasses such value properties of education, which are essential for the educational system itself, a society, a state, an individual;

- compensatory, which allows to fill the lack of knowledge;

- adaptive, which enables an individual to adapt to the constantly changing world, to changes in the sphere of production;

\footnotetext{
${ }^{26}$ Алиева Б. Ш. Ценностные ориентации личности в современной парадигме развития профессионального образования // Вестник бурятского государственного университета. Образование. Личность. Общество. 2017. Вып. 3. С. 15-21. Ст. 17.

27 Грехнев В. С. Ценностные основания процессов образования и образованности людей в современном обществе // Философия и общество. 2010. № 3. С. 40-55. Ст. 44.
} 
- developmental, which allows an individual to maintain social activity and participate in social processes;

- creative, which gives the opportunity to develop the creative potential of an individual at all stages of his life;

- cultural inheritance, which ensures that the personality is attracted to the riches of the world culture and its participation in the preservation, development, enrichment of cultural values;

- transformative, aimed at pedagogizing all spheres of society ${ }^{28}$.

\section{Axiological basis of vocational education}

Let us dwell more on the analysis of the concept of "education as value", which is understood as the result of the evaluative interpretation of a social subject, which can be both a society and a certain social group or personality of the objective value of education, which is expressed in a certain attitude to it.

It is obvious that in the modern world the value of education is increasing, because it is the driving force for the development of both society and every individual, in particular.

Education is becoming a universal value, becoming one of the global problems of today. Being a means of meeting a variety of needs and goals, education becomes a personal value.

Belarusian scientist O. Ivanchina ${ }^{29}$ provides a number of theses that explain the social value of education. First of all, the scientist claims that quality education of the population provides economic growth. We also add that education is also a driving force for social and cultural development. Against this background, the problem of continuing education is becoming more and more relevant in today's world.

\footnotetext{
${ }^{28}$ Сластенин В.А., Чижакова Г.И. Введение в педагогическую аксиологию. М. : Издательский центр Академия, 2003. 192 с. Ст. 135-136.

${ }^{29}$ Иванчина О.Н. Образование как ценность в современном мире // Актуальні проблеми сучасного розвитку цивільного, міжнародного, морського, господарського та транспортного права : Матеріали VII Міжнародної конференції. К. : КДАВТ, 2017. С. 302-304.
} 
The scientist also states that education influences social stratification. On the one hand, education does allow the individual to move from the lower social strata to the higher strata, but current Ukrainian realities do not always support this statement.

We agree with the author's thesis that people with higher levels of education are less likely to commit crimes and also have better opportunities to achieve longevity, because education is an important factor in human cultivation.

We also consider it important to say that education enables one to exercise endless self-realization and self-accentuation ${ }^{30}$.

Modern society is a complex system of human relationships, and in such circumstances, the role of ethical rules is increasing, which would facilitate and streamline the functioning and interaction of people. It should be understood that within society, people are united in different communities: family, sociable, professional, etc. All of them are extremely important, as they are capable of promoting both social progress and regress.

The ethical value inherent in all these groups is the value of "labour". From the pedagogical point of view, it is important to find ways of nurturing the mentioned value, which, however, is impossible without highlighting the essential characteristics of labor as an activity and labor as a value.

Labour is a specific form of activity inherent in a person, aimed at the development and transformation (according to onesr own goals, interests and needs) of the environment, improving social relations (social work) or creating new values (creative work) ${ }^{31}$.

The content, form and orientation of labour are determined by objective and subjective factors. The objective are the historical

\footnotetext{
${ }^{30}$ Иванчина О.Н. Образование как ценность в современном мире // Актуальні проблеми сучасного розвитку цивільного, міжнародного, морського, господарського та транспортного права : Матеріали VII Міжнародної конференції. К. : КДАВТ, 2017. С. 302-304. Ст. 302-303.

31 Філософський енциклопедичний словник / НАН України, Ін-т філософії імені Г. С. Сковороди; [редкол.: В. І. Шинкарук (голова) та ін.]. Київ: Абрис, 2002. 742 с. Ст. 514.
} 
circumstances of the functioning of a society, the interests and needs of the people; the level of development of social production; the availability of natural resources, the impact of globalization on the nature of labour, real working conditions and the life of an employee; he level of education and professional competence of an employee.

Thus, in the Law of Ukraine "On Education" we read: the basis of professional education is "the formation and development of professional competences of a person necessary for professional activity in a particular profession in the relevant field, to ensure one's competitiveness in the labor market and mobility and career prospects for life" 32 .

We agree with B. Gershunskyi ${ }^{33}$, who highlighted four aspects of meaningful interpretation of the notion "education": 1) education as a value; 2) education as a system; 3 ) education as a process; 4) education as a result. Since proffesional education is part of the broad concept "education", the above mentioned aspects also constitute its essential characteristics $^{34}$. Let us dwell on this in details.

Proffesional education can be regarded as a state value, a social value and an individual value. Thus, the Law of Ukraine "On Education" states the following: "Education is the basis of the intellectual, spiritual, physical and cultural development of a person, his successful socialization, economic well-being, the key to the development of a society united by common values and culture, and the state" 35 . In Art. 5 of the law education has been recognized as a state priority that "ensures the innovative, socioeconomic and cultural development of a society. Financing of education is an investment in human potential, a sustainable development of a society and a state". Otherwise, financing of education is an investment in the development of economy, culture, democracy, improving the quality of life

\footnotetext{
32 Закон України - Про освіту - // Відомості Верховної Ради (ВВР). 2017. № 38-39. Ст. 380.

33 Гершунский Б. С. Философия образования. М. : Московский психолого-социальный институт, 1998. 432 c.

34 Гершунский Б. С. Философия образования. М. : Московский психолого-социальный институт, 1998. 432 c.

35 Закон України - Про освіту - // Відомості Верховної Ради (ВВР). 2017. № 38-39. Ст. 380.
} 
and so on. Advance development of the level of education of participants in social production is a prerequisite for economic growth, because the availability of skilled labor provides increased efficiency of production. In addition, education is an important condition for innovative development of a state, which contributes to improving the quality of life of citizens.

For an individual, the level of professional education obtained is one of the indicators of his or her social status. Professional education functionally ensures: positioning and adaptation of an individual in the world of professions; mastering models and norms of professional culture, as well as specialized knowledge; obtaining a certain specialty and the corresponding level of qualification; development of certain areas of human activity, mastering new activities, increase competence and skill. Professional education creates opportunities for becoming not only social but also professional "ego" of an individual, the development and selfrealization of an individual in the sphere of general and professional culture. At the same time, professional education is aimed at the realization of an individual (satisfaction of personal interests and needs), as well as humanistic and democratic social goals ${ }^{36}$.

In the traditional sense, professional education is a system of multi-level institutions that differ in their profile. The Law of Ukraine "On Education",37 distinguishes between the following levels of professional education: vocational, professional pre-higher, higher education and adult education (postgraduate education, vocational training of employees, retraining and /or advanced training courses), continuous professional development).

The purpose of professional education is to shape the professional competences of a person required to undertake the tasks of a professional activity in a particular profession in the relevant field, to ensure competitiveness in the labor market and mobility and career prospects throughout life. Professional education institutions are vocational schools,

\footnotetext{
${ }^{36}$ Климан С. Понятие и сущность профессионального образования. Акмеология профессионального образования. Екатеринбург, 2016. С. 78-82. Ст. 81.

37 Закон України - Про освіту - // Відомості Верховної Ради (ВВР). 2017. № 38-39. Ст. 380.
} 
vocational lyceums, vocational education centers, training and production centers, training courses, training centers, and other types of vocational training institutions.

Developing an educational qualification that confirms a person's ability to perform typical specialized tasks in a particular area of professional activity related to performing tasks of high complexity or the exercise of limited management functions is the task of professional advanced education. This link is expected to be presented by colleges.

Mastering the professional and general competencies of a high level required for pursuing a profession or field is the goal of higher education. This link is represented by such institutions as universities, academies, institutes, colleges.

Instead, the tasks of postgraduate education are to acquire new and improve previously acquired competences based on higher, vocational or professional advanced education or practical experience.

At the heart of building a professional education system is a set of principles that include flexibility, variability, continuity, integrity, and others. Undoubtedly, the system of vocational education should be geared to and adapted to socio-economic conditions, in particular the labor market. At the same time, the current situation compels not only the needs of the state for specialists of different specialties, but, above all, the needs of an individual, who must be competitive in the labor market.

The variability of professional education is to provide the person with the greatest possible number of educational trajectories, which ensures a plurality of types of vocational education institutions, as well as educational and professional programs of training of specialists, variability of the choice of software and methodology etc.

Continuity of professional education involves an organic combination of levels, educational and professional programs, and professional educational institutions as the elements of the professional education system. On the one hand, it helps to ensure the integrity of professional education and on the other - it is an integral part of an individual's life, which corresponds to the 
process of his personal development. Continuity of professional education from vocational to postgraduate and self-education is characterized not only by the presence of levels of the educational system, but also by the special means that provide links between them. Sucha means of communication of forms and content of education is continuity.

Professional education is essentially a process of moving from the goal to the result. The pedagogical process is a holistic pedagogical phenomenon which components are closely interconnected. The purpose is embodied in the content of education, which, in turn, defines the forms and methods of learning that are implemented with the use of certain learning tools. The components of the process of vocational training are: target, incentive-motivational, content, operational-activity, control-regulation, control-effective.

The pedagogical process in a professional education institution has three interrelated functions: educational, upbringing and developmental. The educational function is to form a system of scientific, technological and professional knowledge, the ability to apply the acquired knowledge, skills in practice, etc. Upbringing function involves the formation of scientific outlook, respect for work and people of work, high moral qualities, etc. among the applicants for professional education. Developmental function is manifested in the formation of a future specialists of rational methods of thinking, the improvement of cognitive processes, the formation of a culture of work, etc.

Professional education is also a result that captures the fact of appropriation by both a state and a society, and a personality of all values that are born in the process of professional education, which are important for the economic, moral and intellectual status of consumers of educational products $^{38}$.

The result of professional education is the formation of professional competence and personality culture.

\footnotetext{
${ }^{38}$ Педагогика: Большая современная энциклопедия / сост. Е. С. Рапацевич. Минск : - Современное слово, 2005. 720 с. Ст. 375.
} 
Professional competence is an integrative characteristic of the professional and personal qualities of a specialist, which is a reflection of the level of knowledge, skills, experience that are sufficient to achieve the goal of a certain type of professional activity, as well as the moral position of a specialist. It manifests itself in the readiness for the activity, analysis of the results of work and technological processes, analysis of professional situations and problems, analysis of technical documentation, tasks of the activity, organization of work, compliance with technical and technological requirements of production, coordination of various types of professional activity, possession of professionally important information regarding the object of activity, predicting typical and atypical work situations, proposing safe working conditions, mastering additional qualifications and professions, ensuring a high level of work culture, the rules of operation of industry equipment, timely removal of technical and technological violations, compliance guidelines, standards and requirements for physiological, economic, environmental and ergonomic factors ${ }^{39}$.

Professional competence is a necessary component for bringing personality to culture. This is not just about professional culture, but about culture as the highest manifestation of human education. On the one hand, culture arises through human activity, and on the other, a man is both a consumer and a creator of culture, while becoming a product of culture, because he assimilates the valuesof the environment in which he lives and functions.

At the same time V. Lugovyi considers the values of education as motivating competencies, while noting that the value orientations of an individual are an integral part of professionally important competences ${ }^{40}$. K. Kabryl sticks to that point that considers competence of values for a range of professionally important issues, in which a person is wellinformed, has the necessary knowledge and values that enable him to

\footnotetext{
${ }^{39}$ Енциклопедія освіти / гол. ред. В. Г. Кремінь. К.: Юрінком Інтер, 2008. 1040 с. Ст. 722-723.

40 Луговий В. І. Формування ціннісної компетентності науково-педагогічних працівників - важлива умова їх успішної діяльності в сучасній вищій школі // Проблеми освіти : наук. зб. // Ін-т іннов. технологій змісту освіти МОН України. К., 2010. Вип. 63, Ч. 1. С. 3-9. Ст. 4-8.
} 
express his own professional-evaluative judgments, the ability to see and understand the world around us, orient in it, the ability to choose target and meaningful settings for one's ownr actions and deeds, make correct decisions and value judgments ${ }^{41}$.

The content of the concept of values is so great that their totality forms a coherent system of complex hierarchical structure. In general, they can be represented in the form of the following groups of values: universal, national, civic, professional, personal. Moreover, the value of education has a distinctive essence. On the one hand, it is in the process of education that a person perceives and assimilates the whole system of socially important values, adapts and transforms them into his or her own system of life principles and beliefs, which further determine all his actions and deeds. On the other hand, education, including vocational, is inherently personal and social value, because, both education itself and the knowledge, skills, values, and moral and ethical paradigms acquired in its process have their own special self value - as a prerequisite for effective socio-cultural development of a person and further successful life.

Therefore, the notion "value of professional education" should be considered inseparable with the system of vital values and orientations of a man and a society. First, education, providing natural needs of human knowledge of the facts and of the self, is already creating prerequisites for being one of the most important values in life of a man.

Second, fulfilling their social appointed function training new generations in social life, professional education, along with a certain system of general public and professionally important knowledge and skills should ensure the assimilation of the younger generation all values and ideals, characteristic for this society.

Third, education should now ensure the formation and development of a creative personality ready, including morally and psychologically, to accept

\footnotetext{
${ }^{41}$ Кабриль К. В. Формування ціннісних компетентностей майбутнього вчителя музики у процесі диригентсько-хорової підготовки : автореф. дис. канд. пед. наук : 13.00 .04 / К. В. Кабриль; НАПН України, Ін-т вищої освіти. К., 2013. 20 с.
} 
and create innovations. Such a demand is conditioned by the contemporary realities of social development, accelerated scientific, technological and social progress. In a market economy, the role of creative work is increasing, since it, being free from stereotypes, normativity and tradition, becomes the pledge of material and spiritual well-being of citizens, while reflecting the subjective nature of a man as a free creator of material and spiritual goods, not as mechanical executor of someone else's will. At the same time, it is extremely important and demanded by a society is formed the ability to properly assess the moral and ethical nature of all innovations, their compliance with social and personal needs and requests.

Education, including professional education, is a value to both an individual member of society and to a society as a whole, because it forms the basis of mutual understanding and interaction between its members. For a state, a unified education system is a solid foundation for the constitution of the nation, citizenship, the formation of a single cultural and information space with clearly fixed values. For a society, education is an economic and humanitarian contribution to the future ${ }^{42}$.

\section{CONCLUSIONS}

Today, education in general, and professional education in particular, is one of the necessary branches of human activity for social and personal development. It is an important means of preserving and broadcasting professional and social experience and culture, a catalyst for the personal development of a man, a society and a state, and therefore a driver of personal and social progress. From this position of value issues of professional education is important and was developed by a number of sciences (philosophy, sociology, psychology, pedagogies, etc.). In terms of pedagogy, it is important to distinguish professional values as a system of professionally important ideals and goals that a society lives on. In

\footnotetext{
${ }^{42}$ Иванчина О. Н. Образование как ценность в современном мире // Актуальні проблеми сучасного розвитку цивільного, міжнародного, морського, господарського та транспортного права : Матеріали VII Міжнародної конференції. К. : КДАВТ, 2017. С. 302-304. Ст. 302-303.
} 
addition, professional education is an important regulator of individual activity in various fields of activity, encouraging it to improve itself.

In this way, we can speak that professional education is not only a means of disseminating socially and personally important values, but also itself a personally and socially important value.

\section{SUMMARY}

The results of a theoretical research aimed at studying the axiological nature of professional education are reflected in the paper. The definitions of "education" and "professional education" are given and the lack of an unified approach to their interpretation is established. It is stated that the term "education" is interpreted in the scientific literature: 1) as a value; 2) as a system; 3) as a process; 4) as a result. Since professional education is part of the broad notion "education", these aspects are also its essential characteristics. The value aspects of education are revealed, the personal and social importance of professional education as one of the values of modern world is substantiated. It is proved that the notion "value of professional education" should be considered in unbreakable unity with the system of vital values and orientations of an individual and a society.

\section{REFERENCES}

1. Алиева Б. Ш. Ценностные ориентации личности в современной парадигме развития профессионального образования // Вестник бурятского государственного университета. Образование. Личность. Общество. 2017. Вып. 3. С. 15-21.

2. Батечко Н. Г. Підготовка викладачів вищої школи в умовах магістратури: теоретико-методологічні засади: Монографія / За ред. Я. В. Цехмістера. К.: ТОВ «Видавниче підприємство «ЕДЕЛЬВЕЙС», 2014. $708 \mathrm{c}$.

3. Гегель Г. В. Ф. Работы разных лет / ред. А. В. Гулыга ; пер. Ц. Г. Арзаканьян, В. А. Рубин, Б. А. Драгун и др. М. : Мысль, 1971. T. $2.627 \mathrm{c}$. 
4. Гончаренко С. У. Український педагогічний словник. К. : Либідь, 1997. 376 с.

5. Гершунский Б. С. Философия образования. М. : Московский психолого-социальный институт, 1998. 432 с.

6. Грехнев В. С. Ценностные основания процессов образования и образованности людей в современном обществе // Философия и общество. 2010. № 3. С. 40-55.

7. Енциклопедія освіти / гол. ред. В. Г. Кремень. К. : Юрінком Інтер, 2008. $1040 \mathrm{c}$.

8. Закон України «Про освіту» // Відомості Верховної Ради (ВВР). 2017. № 8-39. Ст. 380.

9. Зубов В. А. Труд в XXI столетии: особенности развития // Молодой ученый. 2016. №6. С. 957-961.

10. Иванчина О.Н. Образование как ценность в современном мире // Актуальні проблеми сучасного розвитку цивільного, міжнародного, морського, господарського та транспортного права : Матеріали VII Міжнародної конференції. К. : КДАВТ, 2017. С. 302-304.

11. Кабриль К. В. Формування ціннісних компетентностей майбутнього вчителя музики у процесі диригентсько-хорової підготовки : автореф. дис. канд. пед. наук : 13.00 .04 / К. В. Кабриль; НАПН України, Ін-т вищої освіти. К., 2013. 20 с.

12. Климан С. Понятие и сущность профессионального образования. Акмеология профессионального образования. Екатеринбург, 2016. C. $78-82$.

13. Ломакина Т. Ю. Современный принцип развития непрерывного образования: монография. М. : Наука, 2006. 221 с.

14. Лосев А. Ф. История античной эстетики. Аристотель и поздняя классика. М. : Искусство, 1975. 776 с.

15. Луговий В. І. Формування ціннісної компетентності науковопедагогічних працівників - важлива умова їх успішної діяльності в сучасній вищій школі // Проблеми освіти : наук. зб. // Ін-т іннов. технологій змісту освіти МОН України. К., 2010. Вип. 63, Ч. 1. С. 3-9. 
16. Невмержицька О. В. Визначення категорії «цінність»: до історіографії проблеми. // Східноєвропейський історичний вісник / [головний редактор В. Ільницький]. Дрогобич : Посвіт, 2017. Вип. 4. 172 с.

17. Педагогика: Большая современная энциклопедия / сост. Е. С. Рапацевич. Минск : «Современное слово», 2005. 720 с.

18. Педагогический энциклопедический словарь / гл. ред. Б. М. Бим-Бад. М. : Большая Российская Энциклопедия, 2003. 527 с.

19. Сластенин В.А., Чижакова Г.И. Введение в педагогическую аксиологию. М. : Издательский центр «Академия», 2003. 192 с.

20. Соціолого-педагогічний словник / за ред. В. В. Радула. Київ : «ЕкОб», 2004. 304 с.

21. Філософський енциклопедичний словник / НАН України, Ін-т філософії імені Г. С. Сковороди; [редкол.: В. І. Шинкарук (голова) та ін.]. К. : Абрис, 2002. 742 с.

22. Фіцула М.М. Педагогіка. К. : «Академвидав», 2005. 560 с.

23. Философский энциклопедический словарь / гл. ред. Л. Ф. Ильичев и др. М. : Сов. энциклопедия, 1983. 839 с.

24. Хуторской А. В. Современная дидактика. СПб. : Питер, 2001.544 c.

25. Ціннісні парадигми освіти / укл. Н. О. Ткачова. Харків : Основа, 2004. 128 с.

\section{Information about the author: \\ Pahuta M. V.}

Candidate of Pedagogic Sciences, Associate Professor, Doctoral Student at the General Pedagogy and Preschool Education Department, Drohobych Ivan Franko State Pedagogical University 24, Ivan Franko str., Drohobych, 82100, Ukraine 